\title{
MANAGEMENT INFLUENCES ON SHEEP BEHAVIOUR, DUNG DISTRIBUTION AND SOIL PHOSPHATE
}

\section{B.S. THORROLD', K.F. O'CONNOR', J.G.H. WHITE

\section{Abstract}

The behaviour of Merino wether hoggets grazing an existing management experiment at Tara Hills High Country Research Station was studied during summer 198111982. The experiment compared three stocking rates and three management systems (continuous, two paddock intermittent grazing, six paddock rotational). The daytime distribution and activity of the hoggets, dung distribution, and Olsen-P levels of topsoils were recorded on ten altitudinal strata within each of the nine treatment areas.

Dung frequency was more closely correlated to grazing distribution than to either resting or total animal distribution. This is contrary to the generally accepted belief that dung accumulation is associated with resting behaviour.

Increasing stocking rate !ed to a more even grazing and dung distribution. Subdivision by itself did not improve the evenness of distribution although it may have enhanced the stocking rate influence.

There was little correlation between dung frequency and soil Olsen$P$ levels, especially outside the night camp areas. This indicates the importance of factors such as plant uptake and herbage consumption in the phosphate nutrient cycle.

Olsen- $P$ levels were consistently higher in the high stocking rate paddocks relative to the low stocking rate. Levels in the medium stocking rate fluctuated between these two.

The implications of these findings in regard to the effects of intensification of farming in the high country on nutrient cycling and fertiliser requirements are discussed.

Keywords: animal behaviour, dung distribution, tussock grasslands, phosphate, grazing management.

\section{INTRODUCTION}

The importance of nutrient return through dung and urine in the nutrient cycles of grassland systems is well recognised. Although beneficial in returning nutrients to the soil in a plant-available form, the uneven distribution of this return causes accumulation of nutrients in small areas in excess of plant requirements, with the risk of high losses of some nutrients through leaching and volatilisation. In the phosphorus (P) cycle, accumulation of dung in campsites has been associated with transfer of P into such sites (Hilder, 1966; Gillingham \& During, 1973; Gillingham, 1983). The amount of $P$ lost from the cycle through uneven return will influence the maintenance phosphate requirements of a pasture. Gillingham (1982) has presented evidence indicating more uneven dung return in paddocks where a small proportion of easy terrain was associated with a large proportion of steep terrain. Cornforth \& Sinclair (1982) estimate an increased animal-related $P$ loss per stock unit with increasing land slope.

1 Plant Science Department - now MAF Rotorua

2 Professor of Range Management

3 Professor of Agronomy 
Clearly then, factors which increase the evenness of dung return could lead to reduced fertiliser requirements. Gillingham (1982) suggested that subdivision of paddocks into slope classes would improve the evenness of dung return. There is also evidence from Donald \& Leslie (1969) that, under sheep grazing, subdivision and increased stocking rate can lead to a more even dung return. Although camping behaviour in sheep has been observationally connected with the pattern of dung return, there has been little research into this association. Crofton(1958), in one study with sheep, found that dung accumulated initially in areas which were not grazed during the day, and that the site of accumulation shifted over time.

Increasing intensification of farming in the high country may lead to changes in animal behaviour and dung distribution which could have important implications for nutrient cycling and fertiliser requirements.

This study aimed to clarify possible relationships between animal behaviour and dung distribution, to examine changes in these related to the management treatments applied, and to investigate the relationship between soil phosphate levels and dung return.

\section{METHODS}

The observations reported in this paper were made on 24 days in the period November 1981 to January 1982 at Tara Hills High Country Research Station, Omarama. The animals observed were Merino wether hoggets grazing an established management experiment comprising nine paddocks on 16 ha of south-east facing steep hill slope $(30 ")$ of oversown and topdressed blue tussock grassland ranging from $760 \mathrm{~m}$ to $930 \mathrm{~m}$ a.s.I. (Allan, 1985). This constituted the single block in a $3 \times 3$ factorial design of three grazing systems (continuous, two paddock intermittent, six paddock rotational) and three stocking rates (low, medium, high in the ratio 1.0:1.5:2.0). Paddocks were subdivided vertically in the two paddock treatments and by two vertical and one horizontal mid slope fence in the six paddock treatments. The long term stocking rates for the trial for the three years to 1982 had been 1.91, 2.98 and 4.08 stock units ha-I yr-1. The experiment was grazed from November to April each year. The low stocking rate, seasonally continuous management combination is standard practice in much of the tussock grasslands.

From a vantage point on an opposite slope, animal activities were observed in each of ten cells together comprising the whole of each paddock. The cells were of equal area and were numbered 1 to 10 in order from the top of the slope to the bottom. In paddock A (high, continuous), paddock shape did not allow cells of equal size by altitudinal division so appropriate data corrections have been made. Numbers of animals and types of activity in each cell were recorded every half hour between $6.30 \mathrm{am}$ and $9.30 \mathrm{pm}$. Activities recorded were aggregated for analysis into resting (lying or standing or sheltering) and grazing (walking or grazing). Sheep were also recorded drinking and at salt blocks at observation times.

Soil samples for MAF Quicktest analysis were collected from 0-100 mm depth in April 1982 in a detailed pattern of 7 or 8 altitudinal strata that allowed results to be related to those obtained from more limited sampling at the beginning of the experiment in 1979. Where these strata did not coincide with cells outlined above, values were interpolated.

Dung frequency counts were made on 21-23 January 1982 at the end of the observation period, recording presence or absence in a $250 \mathrm{~cm}$ ' quadrat (Gillingham, 1980). Two recorders each made six transects of 20 metres length per Cell, recording at 1 metre intervals. No estimation was made of dung weight.

\section{RESULTS}

Animal distribution patterns over all treatments showed common topographyrelated trends which had three major characteristics; 


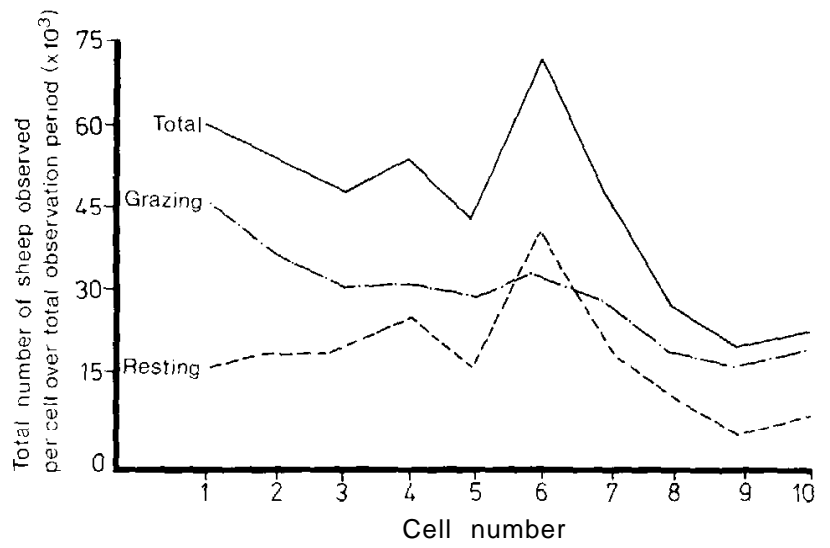

Figure 1: Distribution of sheep and their activities from top of slope (cell 1) to bofrom of slope (cell 10) summed from all observations on nine treatment areas.

(i) grazing occupancy decreased down the slope (Figures 1 and 2);

(ii) daytime resting distribution showed no altitudinal gradient (Figure 1) and was relatively less uniform than grazing distribution, sheep showing consistent preference for certain areas;

(iii) as a consequence of (ii), the daytime resting pattern tended to dominate the total occupancy pattern although resting never accounted for more than half of total observations (Figure 1).

This last influence was not dominant in two treatments, the high six and medium two, where resting distribution was relatively even, due to effects of high stock density and variation in topography between sub-paddocks respectively.

\section{Grazing DIstributlon}

Grazing distribution showed an overall response to stocking rate, with grazing occupancy showing somewhat less variation with altitude at the high stocking rate (Figure 2a). Figure $2 \mathrm{~b}$ shows clearly that the only effect of management systems was a small redistribution of activity related to the mid-slope fence between cells 5 and 6 . Altitude-related gradients existed in each sub-paddock.

\section{Resting Distribution}

Stocking rate and management system did not affect resting distribution, except for a small increase in resting occupancy of the lower five cells associated with the mid-slope fence. Distribution of night camping was observed in late evening and early morning but was not systematically recorded. Sheep appeared consistently to camp during the night at the top of the paddock or sub-paddock they were in. Although this may be a "night camping on high ground" phenomenon, it may also have been associated with slope as the top cells in each paddock tended to be less steep than others.

In all treatments the sheep displayed a consistent attraction to particular areas for resting during the day. Only in the bottom half of the six paddock treatment did the sheep rest during the day in the night-camp area. The preference for particular areas appeared to be largely related to micro-topography, sheep preferring to rest on small terraces. There did not appear to be any association between neighbouring groups in selection of rest sites during the observation period. 


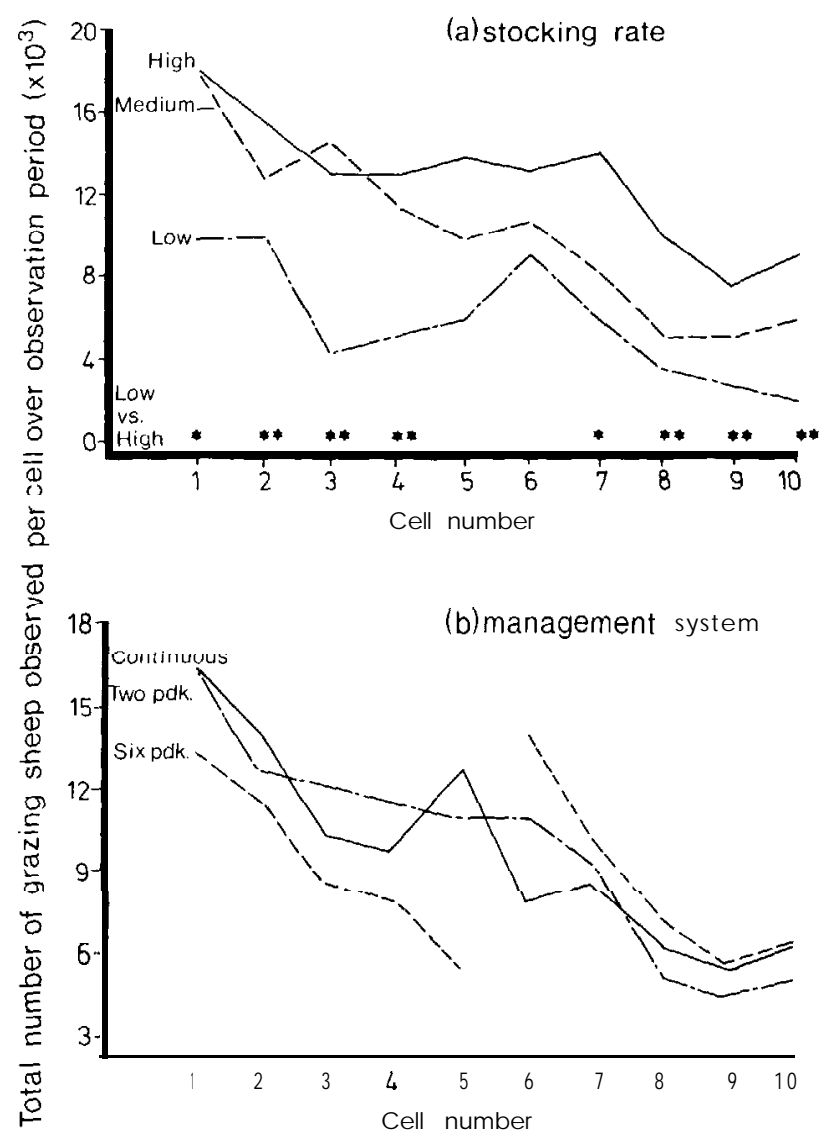

Figure 2: Influence of stocking rate and management system on distribution of grazing activity of sheep.

\section{Dung Distribution}

Dung distribution patterns showed a higher frequency of dung with increased stocking rates in all cells and a more even spread (Figure 3a). The range of frequency at the low stocking rate $(6.5$ to 13.5$)$ was greater than at the high stocking rate (12.5 to 15). Dung frequency at the medium stocking rate was intermediate with a range similar to the low stocking range.

Management system effects on dung distribution were related mainly to the influence of the mid-slope fence on animal distribution (Figure $3 b$ ). There was a decrease in the frequency of dung in the upper sub-paddock of the rotational treatments balanced by an increase in cells 6 and 7 in the lower sub-paddocks.

\section{Olsen-P Distribution}

Olsen-P levels in the high stocking rates were 3 to 12 test units higher than the low stocking rate, although each followed a similar pattern down the slope (Figure 4). While this difference was significant $(p<0.05)$ overall, the high degree of variation made within cell comparisons non-significant. The medium stocking rate followed the trends of the low stocking rate in the upper3 cells and of the high stocking rate in the lower 6 cells. 

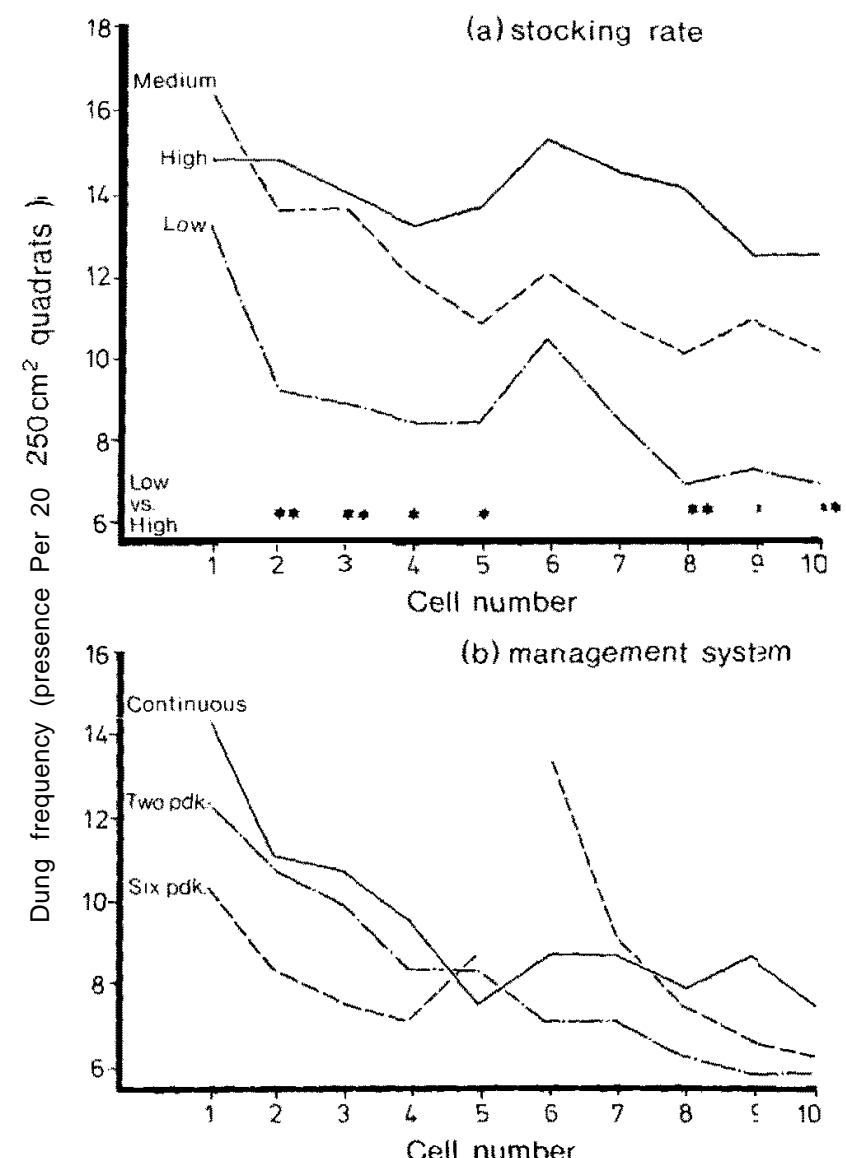

Figure 3: Influence of stocking rate and management system on distribution of frequency of occurrence of sheep dung at end of observation period.

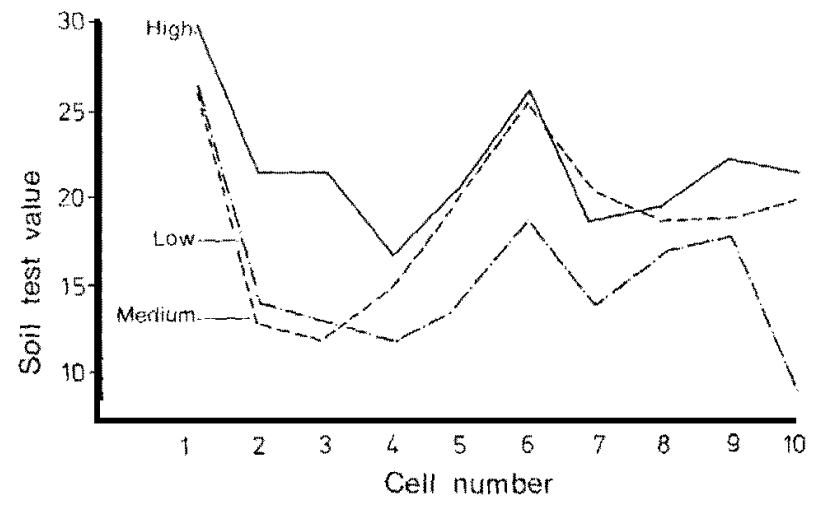

Figure 4: Influence of stocking rate on distribution of Oisen-P soil test values for $0-100 \mathrm{~mm}$ soll depth. 
There was an increase in Olsen-P in cell 6 of the six paddock systems, associated with apparent night-camp areas.

\section{DISCUSSION}

\section{Influences on dung distribution}

The influence of sheep distribution on dung frequency was an important facet of this study. Dung frequency was generally highest in those cells apparently occupied as night-camps. However, there was no consistent pattern of dung accumulation in the day rest areas. This was unexpected in the view of the commonly held association between resting and defecation (Sears 1950; Hilder, 1966) and the fact that sheep spent as much time in the day resting areas as they could have spent resting in the night camps.

Table 1 shows that for all cells dung frequency was more closely correlated with grazing occupancy than with resting occupancy. This was found to be true also when the night-camp cells were omitted. This suggests that grazing distribution is the dominant influence, other than night camping, on the pattern of dung deposition in this experiment, and consequently that changes in grazing distribution induced by treatments may cause changes in dung distribution.

Table 1: CORRELATION COEFFICIENTS BETWEEN OBSERVED PARAMETERS FOR A) ALL CELLS; B) CELLS OTHER THAN NIGHT-CAMPS.

\begin{tabular}{|c|c|c|c|c|c|}
\hline & $\begin{array}{c}\text { Soil } \\
\text { Olsen-P }\end{array}$ & $\begin{array}{c}\text { Dung } \\
\text { frequency }\end{array}$ & $\begin{array}{c}\text { Grazing } \\
\text { occupancy }\end{array}$ & $\begin{array}{c}\text { Resting } \\
\text { occupancy }\end{array}$ & $\begin{array}{c}\text { Total } \\
\text { occupancy }\end{array}$ \\
\hline \multicolumn{6}{|c|}{ (a) } \\
\hline Olsen-P & (b) & $0.433^{\star} \ldots$ & $0.282^{* \star}$ & 0.050 & 0.182 \\
\hline frequency & 0.272 , & - & 0.774 * * & $0.396 * * *$ & $0.666^{\prime} \cdot$. \\
\hline Grazing occupancy & 0.061 & $0.730^{* * *}$ & - & $0.441^{* * *}$ & $0.814^{* * *}$ \\
\hline Resting occupancy & 0.047 & $0.412^{\star \star \star}$ & $0.489 * * \star$ & $\longrightarrow$ & $0.880^{\prime} \ldots$ \\
\hline Total occupancy & 0.000 & $0.638^{*}$ & $0.821 * * *$ & $0.899 "$ & ' \\
\hline
\end{tabular}

As Figure $3 b$ shows, there was little change in the gradient of dung distribution associated with management system. Gillingham (1982) likewise found no discernible effect on dung distribution when varying the duration of grazing from 3 to 15 days at a common pasture allowance per sheep grazing day. In a year-long comparison of continuous grazing with rotational grazing for $2-3$ days at a time Gillingham (1983) found little modifying influence of grazing system on the dominant effect of topography.

The major changes in dung distribution in this study were related to stocking rate with the high stocking rate producing a more even dung distribution than the medium or low. In a review of animal influences on nutrient transfer, Gillingham (1983) suggested that the excretal distribution pattern from grazing sheep might be influenced more by variations in residual herbage mass either maintained (continuous grazing) or grazed to (rotational grazing) than by the type of grazing system adopted. In the present study such variations in residual herbage mass were achieved by varying stocking rates. The influence these had on animal grazing behaviour was reflected in changes in the dung distribution pattern.

In the present study area there was relatively little variation in macro-topography so that it was not possible to assess the relative importance of altitude and slope variation on the behaviour of the animals studied.

Stocking rate modified the altitude-related effects on grazing behaviour in this experiment as it did in another study in the Mackenzie Country (Scott \& Sutherland, 1981). The influence of stocking rate on slope-related grazing behaviour can be 
inferred from the higher and more even utilisation of hill country of varying topography with increased stocking rate (Suckling 1975), presumably brought about by a reduced potential for selective grazing. This in turn should modify the influence of slope on dung accumulation patterns,

Table 2: RELATIONSHIPS BETWEEN GRAZING OCCUPANCY AND DUNG FREQUENCY FOR ALL CELLS WITHIN (A) STOCKING RATES AND (B) MANAGEMENT SYSTEMS.

Regression coefficient

Correlation coefficient

$r$

\begin{tabular}{lll}
\hline (a) Stocking rates & & \\
High & 0.00032 & 0.30 ns \\
Medium & 0.00136 & $0.83 * *$ \\
Low & 0.00191 & $0.85 *$ \\
(b) Management systems & & \\
Continuous & 0.00166 & $0.74 * *$ \\
Intermittent & 0.00144 & $0.85 * *$ \\
Rotationai & 0.00174 & $0.77 * *$ \\
\hline
\end{tabular}

Table 2 shows that the relationship between dung frequency and grazing distribution was essentially similar among different management systems. However, at the high stocking rate the same close relationship between dung frequency and grazing occupancy did not exist as occurred at the low and medium stock rates. Since there was an overall relationship between dung frequency and grazing occupancy, this lack of correlation might be explained by the influence of unobserved night grazing on dung distribution.

influences on Olsen-P levels

Hilder (1966) and Gillingham \& During (1973) measured available soil phosphate levels which followed a pattern similar to the measured dung return. While there is a trend of higher Olsen- $P$ values with higher stocking rates, Table 1 shows that in this study there was not a very close correlation between dung frequency and Olsen-P level, especially outside of the night camp areas. Dung frequency and dung weight per unit area are not always proportionally related (Gillingham 1982, 1983). The lack of close relationships between dung frequency and soil Olsen-P level is therefore not conclusive. There is some evidence, however, that apart from the night-camp areas, dung deposition was not the predominant influence on soil phosphate status in this study. Other plant nutrients such as sulphur or nitrogen, uneven phosphate fertiliser application, soil erosion and climatic factors may also influence the relative phosphate enrichment or depletion of various strata. Initial soil tests indicated that gradients in soil phosphate existed on this site before the experiment began (B.E. Allan, pers. comm.) and a full consideration of changes in soil phosphate must await completion of analyses.

However it is mediated, the relationship between stocking rate and soil Olsen-P levels remains of considerable importance. This effect suggests that differences exist in the pool sizes and rates of passage in the phosphate cycle. At the high stocking rate pasture utilisation is high (B.E. Allan pers. comm.) with most phosphate being returned to the soil more evenly as dung, perhaps in forms which are soon measured by the Olsen test. At the low stocking rate utilisation is low with more phosphate returning to the soil pool as litter, in organic forms more slowly released into the plant available pool, or remaining in the standing herbage mass. 
Cornforth \&Sinclair (1982) use constant per stock unit animal loss factors in the Superchoice model. In the situation studied here, an increase in stocking rate has evidently led to reduced per stock unit animal-related losses through a more even dung distribution, lower per animal liveweight gains and wool weight (B.E. Allan, pers. comm.). Such an influence on the amount of $P$ lost may be additional to the influence which higher utilisation may have in reducing maintenance $P$ requirements through increasing the size at the labile $\mathrm{P}$ pool and the rate of $\mathrm{P}$ cycling through the system.

While there is considerable risk involved in extrapolating from this study with its relatively controlled and uniform conditions to a larger scale operation, the conclusions drawn here concerning the effects of stocking rate on animal behaviour patterns and consequent influences on dung distribution and nutrient cycling should be considered and evaluated In other situations where animal-related $P$ losses might comprise a large part of the maintenance fertiliser requirement.

This study has illustrated the importance of animal behaviour in this environment. It appears that important changes which occurred in dung patterns and Olsen-P levels can be related to changes in behaviour brought about by the treatments imposed. With increasing intensification of farming in the high country, the study of animal behaviour appears likely to yield valuable information to improve efficiency of production and reduce costs,

\section{ACKNOWLEDGEMENTS}

The authors gratefully acknowledge the cooperation and criticism of B.E. Allan in this work as well as his sharing of soil test results. M.H. Douglas, Officer in Charge

at Tara Hills is thanked for encouragement and logistical assistance.

\section{REFERENCES}

Allan, B.E. 1985. Proc. N.Z. Grassld Ass. 46: 119-125.

Cornforth, I.S.; Sinclair, A.G. 1982. N.Z. J. exp. Agric. 10: 53-62.

Grofton, H.D. 1958. Parasitology 48: 251-260.

Donald, A.D.; Leslie, R.T. 1969. Ibid 59: 141-157.

Gillingham, A.G. 1980. N.Z. J. agric. Res. 23: 313-321. 1982. Proc. NZ Grassld Ass. 43: 161.170.

1983. In: "Foothills for Food and Forests" (ed. David B. Hannaway).

Oregon State University. pp 73-94. ; During, C. 1973. N.Z. J. exp. Agric. 7: 227-232.

Hilder, E.J. 1966. Proc. VIIth Int. Grass/d Cong. 977-981.

Scott, D.; Sutherland, B.L. 1981. N.Z. J. exp. Agric. 9: 1-9.

Sears, P.D. 1950. J.Brit. Grass/d Soc. 5: 267.80.

Suckling, F.E.T. 1975. N.Z. J. exp. Agric. 3: 351-436. 